\title{
PENERAPAN DATA MINING DALAM MENGELOMPOKAN PRODUKSI JAGUNG MENURUT PROVINSI MENGGUNAKAN ALGORITMA K-MEANS
}

\author{
Nanda Erlangga ${ }^{1}$, Solikun $^{2}$, Irawan $^{3}$ \\ ${ }^{1}$ Mahasiswa STIKOM Tunas Bangsa, Pematangsiantar, Indonesia \\ ${ }^{2,3}$ Dosen STIKOM Tunas Bangsa, Pematangsiantar, Indonesia \\ Email: ${ }^{1}$ erlanggananda944@gmail.com, ${ }^{2}$ solikhun@amiktunasbangsa.ac.id, ${ }^{3}$ irwan@ amiktunasbangsa.ac.id,
}

\begin{abstract}
Abstrak
Kebutuhan jagung saat ini mengalami perkembangan yang cukup pesat dapat dilihat dari segi pasar domestik, disini peneliti ingin meningkatkan produktifitas serta kualitas produksi jagung. Data yang akan digunakan adalah data Badan Pusat Statistik. Metode dalam penelitian ini adalah Algoritma $K$-means clustering dan aplikasi yang digunakan adalah Rapidminer yang nantinya dikelompokkan menjadi 2 clustering yaitu tinggi dan rendah. Hasil dari penelitian ini ada 2 provinsi cluster tingkat tinggi, 32 provinsi cluster tingkat rendah
\end{abstract}

.Kata Kunci: Jagung, Data mining, K-means Clustering

\begin{abstract}
Corn needs are currently experiencing a fairly rapid development can be seen in terms of the domestic market, here researchers want to increase the productivity and quality of corn production. The data that will be used is the data from the Central Statistics Agency. The method in this study is the K-means clustering algorithm and the application used is Rapidminer which will be grouped into 2 clustering, namely high and low. The results of this study are 2 high level cluster provinces, 32 low level cluster provinces
\end{abstract}

Keywords: Corn, Data mining, K-means Clustering c

\section{PENDAHULUAN}

Indonesia merupakan negara agraris yang diberi berkah kekayaan alam yang berlimpah baik sumber daya alam hayati maupun non hayati. Berbagai hasil alam tumbuh subur di Indonesia termasuk tanaman pangan. Tanaman pangan merupakan tanaman penting menyangkut fungsi utama sebagai bahan makanan utama masyarakat indonesia, salah satu tanaman pangan bagi masyarakat Indonesia adalah jagung.

Jagung merupakan salah satu tanaman pangan dunia yang terpenting selain gandum dan padi. Penduduk di beberapa daerah di Indonesia juga menggunakan jagung sebagai pangan pokok selain sebagai sumber karbohidrat, jagung yang telah direkayasa genetika juga sekarang ditanam sebagai penghasil bahan farmasi. Selain untuk pangan jagung juga banyak digunakan industri makanan, minuman dan kimia. Pemanfaatan jagung sebagai bahan baku industri akan memberi nilai tambah bagi usahatani komoditas tersebut. Dalam bentuk biji utuh, jagung dapat diolah misalnya menjadi tepung jagung, beras jagung, dan makanan ringan dapat pula diproses menjadi minyak goreng, margarin dan forrmula makanan. Perkembangan ini juga membuat penelitian mengenai karakteristik semakin dinamis, oleh karena itu penelitian yang terkait karakteristik terus dikembangkan.

Selain itu Kebutuhan jagung saat ini mengalami peningkatan dapat dilihat dari segi produksi yang dimana permintaan pasar domestik ataupun internasional yang sangat besar untuk kebutuhan pangan ataupun pakan. Sehinngga hal ini memicu para peneliti untuk menghasilkan varietas-varietas jagung yang lebih unggul guna lebih meningkatkan produktifitas serta kualitas agar persaingan di pasar dapat lebih meningkat yang nantinya akan menghasilkan 2 kelompok daerah produksi tanaman jagung tinggi dan daerah produksi tanaman jagung rendah.

Kajian penelitian terdahulu (Rosmini, 2018) yang berjudul "Implementasi Metode K-Means Dalam Pemetaan Kelompok Mahasiswa Melalui Data Aktivitas Kuliah" menyimpulkan bahwa, Cluster A adalah mahasiswa yang lulus tepat waktu sedangkan cluster B adalah mahasiswa yang lulusnya tidak tepat waktu, dan Data pengelompokan mahasiswa ini merupakan masukan bagi dosen wali dalam membimbing dan mengawasi proses belajar mahasiswa agar bisa lulus tepat waktu. Begitu juga dengan penelitian [1] yang berjudul "Pengelompokan Wilayah Berdasarkan Potensi Hasil Pertanian Menggunakan Algoritma K-means Di Kota Cilegon” menyimpulkan bahwa, Dari hasil analisa perhitungan data menggunakan Algoritma K-means ini untuk memudahkan pemerintah memperoleh informasi data pengelompokan wilayah diharapkan hasil dari pengelompokan dapat dijadikan bahan pengambil kebijakan terkait peningkatan hasil pertanian setiap kecamatan dimasa mendatang, sehingga dapat membantu untuk mengoptimalkan program-program pemerintah di bidang pertanian.

Diharapkan penelitian ini dapat memberikan manfaat dan rekomendasi bagi pemerintah untuk meningkatkan lagi produksi jagung di indonesia agar petani di Indonesia dapat mencukupi kebutuhan masing-masing dengan maksimal.

\section{METODOLOGI PENELITIAN}

\subsection{Data Mining}


Data Mining merupakan proses maupun kegiatan mengumpulkan sekumpulan data dalam jumlah yang besar untuk di ekstraksi sehingga menjadi informasi yang dapat digunakan[1]. Data mining adalah proses yang menggunakan teknik statistik, matematika, kecerdasan buatan, dan machine learning untuk mengekstraksi dan mengidentifikasi informasi yang bermanfaat dan pengetahuan yang terkait dari database yang besar. Tujuan utama data mining adalah untuk menemukan, menggali, atau menambang pengetahuan dari data atau informasi yang kita miliki [2].

\subsection{Cluster}

Menurut Baskoro cluster atau klusterisasi adalah salah satu alat bantu pada data mining yang bertujuan mengelompokkan objek-objek ke dalam cluster - cluster. Cluster adalah metode penganalisaan data, yang sering dimasukkan sebagai salah satu metode Data mining, yang tujuannya adalah untuk mengelompokkan data dengan karakteristik yang sama ke suatu wilayah yang sama dan data dengan karakteristik yang berbeda ke wilayah yang lain [3]. Cluster berbeda dari klasifikasi karena cluster tidak memiliki variabel target. Tujuan cluster bukan untuk mengklasifikasikan, memperkirakan, atau memprediksi nilai variabel taget.

\subsection{K-Means}

K-Means merupakan suatu algoritma yang digunakan dalam pengelompokkan secara pertisi yang memisahkan data ke dalam kelompok yang berbeda-berda. Algoritma ini mampu meminimalkan jarak antara data ke cluster nya [4].

Secara umum algoritma $K$-Means memiliki langkah-langkah dalam pengelompokan

1. Inisilisasi: menentukan nilai $K$ centroid yang diinginkan dan metrik ketidakmiripan (jarak) yang diinginkan.

2. Memilih $K$ data dari set $X$ sebagai centroid. Untuk menentukan centroid dapat menggunakan persamaan.

Jumlah Data

\section{$\overline{\text { Jumlah Class }+1}$}

3. Mengalokasikan semua data ke centroid terdekat dengan matrik jarak yang telah ditetapkan.

4. Menghitung kembali centroid $C$ berdasarkan data yang mengikuti cluster masing - masing.

5. Mengulangi langkah 3 dan 4 hingga kondisi konvergen tercapai.

Berikut ini adalah rumus untuk menentukan jumlah cluster:

$$
K=\sqrt{\frac{N}{2}}
$$

Keterangan:

$\mathrm{K}=$ klaster

$\mathrm{N}=$ jumlah data

Menghitung jarak pada ruang jarak Euclidean menggunakan formula:

$$
\begin{aligned}
& D\left(x_{2}, x_{1}\right)=\left\|x_{2}-x_{1}\right\|_{2} \\
& \sqrt{\sum_{j=1}^{p}\left|x_{2 j}-x_{1 j}\right|^{2}}
\end{aligned}
$$

Keterangan:

$D=$ euclidean distance

$x$ = banyaknya objek

$\Sigma^{P}=$ jumlah data record

\section{HASIL DAN PEMBAHASAN}

\subsection{Analisis Data}

Analisis data merupakan cara yang digunakan untuk menjawab masalah penelitian melalui prosedur pengelolahannya terutama masalah yang berkaitan dengan penelitian. Data yang diperoleh untuk penelitian ini

\begin{tabular}{|c|c|c|c|c|c|c|}
\hline \multirow{2}{*}{ Provinsi } & \multicolumn{6}{|c|}{ Produksi (Ton) Jagung } \\
\hline & 2010 & 2011 & 2012 & 2013 & 2014 & 2015 \\
\hline ACEH & 167090 & 168861 & 167285 & 177842 & 202318 & 205125 \\
\hline SUMATERA UTARA & 1377718 & 1294645 & 1347124 & 1183011 & 1159795 & 1519407 \\
\hline SUMATERA BARAT & 354262 & 471849 & 495497 & 547417 & 605352 & 602549 \\
\hline RIAU & 41862 & 33197 & 31433 & 28052 & 28651 & 30870 \\
\hline JAMBI & 30691 & 25521 & 25571 & 25690 & 43617 & 51712 \\
\hline SUMATERA SELATAN & 125796 & 125688 & 112917 & 167457 & 191974 & 289007 \\
\hline
\end{tabular}
adalah produksi jagung dari tahun 2010-2015

Tabel 1. Data BPS/Penelitian 
BENGKULU

LAMPUNG

KEP. BANGKA BELITUNG

KEP. RIAU

DKI JAKARTA

JAWA BARAT

JAWA TENGAH

DI YOGYAKARTA

JAWA TIMUR

BANTEN

BALI

NUSA TENGGARA BARAT

NUSA TENGGARA TIMUR

KALIMANTAN BARAT

KALIMANTAN TENGAH

KALIMANTAN SELATAN

KALIMANTAN TIMUR

KALIMANTAN UTARA

SULAWESI UTARA

SULAWESI TENGAH

SULAWESI SELATAN

SULAWESI TENGGARA

GORONTALO

SULAWESI BARAT

MALUKU

MALUKU UTARA

PAPUA BARAT

PAPUA

INDONESIA

$\begin{array}{rr}74331 & 87362 \\ 2126571 & 1817906 \\ 1055 & 850 \\ 961 & 923 \\ 31 & 23 \\ 923962 & 945104 \\ 3058710 & 2772575 \\ 345576 & 291596 \\ 5587318 & 5443705 \\ 28557 & 13863 \\ 66355 & 64606 \\ 249005 & 456915 \\ 653620 & 524638 \\ 168273 & 160819 \\ 9345 & 9208 \\ 116449 & 99779 \\ 11993 & 7341 \\ - & - \\ 446144 & 438504 \\ 162306 & 161810 \\ 1343044 & 1420154 \\ 74840 & 67997 \\ 679167 & 605782 \\ 58020 & 82995 \\ 15273 & 13875 \\ 20546 & 26149 \\ 1931 & 2125 \\ 6834 & 6885 \\ 18327636 & 17643250\end{array}$

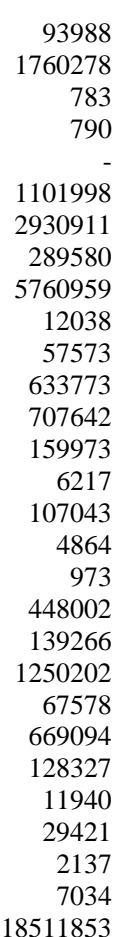

52785

$\begin{array}{rr}1719386 & 1502800 \\ 721 & 666\end{array}$

$703 \quad 473$

$\begin{array}{rr}0 & 959933 \\ 1047077 & 3212391\end{array}$

$3051516 \quad 3212391$

$312236 \quad 299084$

$5737382 \quad 6131163$

$10514 \quad 11870$

$40613 \quad 40603$

$785864 \quad 959973$

$647108 \quad 685081$

$135461 \quad 103742$

$8138 \quad 8189$

$117986 \quad 128505$

$7567 \quad 8379$

$1235 \quad 1032$

$488362 \quad 300490$

$170203 \quad 131123$

$1490991 \quad 1528414$

$60600 \quad 68141$

$719780 \quad 643512$

$110665 \quad 100811$

$10568 \quad 13947$

$19555 \quad 11728$

2450

$7282 \quad 6666$

$19008426 \quad 19612435$

$\mathrm{R} 1=167090 / 168861 / 167285 / 177842 / 202318 / 205125 / 6=181420,17$

$\mathrm{R} 2=1377718 / 1294645 / 1347124 / 1183011 / 1159795 / 1519407 / 6=13136167$

$\mathrm{R} 3=354262 / 471849 / 495497 / 547417 / 605352 / 602549 / 6=512821,00$

R4 = 41862/33197/31433/28052/28651/30870/6 = 32344, 17

R5 = 30691/25521/25571/25690/43617/51712 = 33800,33

Samapai R34, dan berikut adalah nilai rata-rata untuk iterasi 1

1. Menetapkan nilai k jumlah cluster produksi tanaman jagung sebanyak 2 cluster (k-2). Cluster yang dibentuk yaitu claster tertinggi dan cluster terendah.

Iterasi 1

Tabel 2. Hasil perhitungan jarak data ke titik pusat cluster (Iterasi 1)

\begin{tabular}{llll}
\hline \multicolumn{1}{c}{ Provinsi } & \multicolumn{1}{c}{ c1 } & \multicolumn{1}{c}{ c2 } & iterasi 1 Jarak terpendek \\
\hline ACEH & 5644551,17 & 181408,17 & 181408,17 \\
SUMATERA UTARA & 4512354,67 & 1313604,67 & 1313604,67 \\
SUMATERA BARAT & 5313150,33 & 512809,00 & 512809,00 \\
RIAU & 5793627,17 & 32332,17 & 32332,17 \\
JAMBI & 5792171,00 & 33788,33 & 33788,33 \\
SUMATERA SELATAN & 5657164,83 & 168794,50 & 168794,50 \\
BENGKULU & 5745139,17 & 80820,17 & 80820,17 \\
LAMPUNG & 4044768,67 & 1781190,67 & 1781190,67 \\
KEP. BANGKA & & & \\
BELITUNG & 5825131,00 & 828,33 & 828,33 \\
KEP. RIAU & 5825188,17 & 771,17 & 771,17 \\
DKI JAKARTA & 5825959,33 & 0,00 & 0,00 \\
JAWA BARAT & 4824850,17 & 1001109,17 & 1001109,17 \\
JAWA TENGAH & 2814682,50 & 3011276,83 & 2814682,50 \\
DI YOGYAKARTA & 5513524,67 & 312434,67 & 312434,67 \\
JAWA TIMUR & 0,00 & 5825959,33 & 0,00 \\
BANTEN & 5811527,83 & 14431,50 & 14431,50 \\
BALI & 5770700,83 & 55258,50 & 55258,50 \\
NUSA TENGGARA & & & \\
BARAT & 5204604,00 & 621355,33 & 621355,33 \\
NUSA TENGGARA & & & \\
TIMUR & 5184725,50 & 641233,83 & 641233,83 \\
KALIMANTAN BARAT & 5676239,50 & 149719,83 & 149719,83 \\
& &
\end{tabular}

Page $\mid 704$

http://ejurnal.stmik-budidarma.ac.id/index.php/komik 


KALIMANTAN
TENGAH
KALIMANTAN
SELATAN
KALIMANTAN TIMUR
KALIMANTAN UTARA
SULAWESI UTARA
SULAWESI TENGAH
SULAWESI SELATAN
SULAWESI TENGGARA
GORONTALO
SULAWESI BARAT
MALUKU
MALUKU UTARA
PAPUA BARAT
PAPUA

\begin{tabular}{lll}
5817797,33 & 8162,00 & 8162,00 \\
& & \\
5712333,33 & 113626,00 & 113626,00 \\
5817624,00 & 8335,33 & 8335,33 \\
5824891,33 & 1068,00 & 1068,00 \\
5399003,00 & 426956,33 & 426956,33 \\
5674911,83 & 151047,50 & 151047,50 \\
4401282,33 & 1424677,00 & 1424677,00 \\
5756370,83 & 69588,50 & 69588,50 \\
5165623,17 & 660336,17 & 660336,17 \\
5725409,33 & 100550,00 & 100550,00 \\
5811990,67 & 13968,67 & 13968,67 \\
5803814,33 & 22145,00 & 22145,00 \\
5823812,00 & 2147,33 & 2147,33 \\
5819122,33 & 6837,00 & 6837,00 \\
\hline
\end{tabular}

2 Menentukan nilai centroid (pusat cluster) awal yang telah ditentukan berdasarkan nilai variabel data yang di cluster sebanyak yang ditentukan sebelumnya. Adapun cluster tertinggi diperoleh dari nilai tertinggi pada, cluster rendah diambil dari nilai rata-rata dan cluster terendah

\begin{tabular}{cc} 
Tabel 3.Centroid data awal (Iterasi 1) \\
\hline Max & 5825971,33 \\
Min & 12,00
\end{tabular}

3 Menghitung jarak setiap data produksi tanaman jagung terhadap pusat cluster. Setelah data nilai pusat claster awal ditentukan, maka langkah selanjutnya adalah menghitung jarak masing-masing data terhadap pusat cluster dengan menggunakan rumus yang perhitungannya dapat kita lihat sebagai berikut:

Dilakukan perhitungan jarak terhadap data produksi tanaman jagung dengan titik pusat (centroid) pada cluster pertama

$\mathrm{D}(1.1)=\sqrt{(5825971,33-181420,17})^{2}=5.644 .511$
$\mathrm{D}(1.2)=\sqrt{(5.825 .971-1.313 .617)^{2}}=4.512 .354$
$\mathrm{D}(1.3)=\sqrt{(5.825 .971-512.821)^{2}}=5313150,33$

Sampai dengan $\mathrm{D}(1.34)$

Perhitungan produksi tanaman jagung pertama dengan centroid cluster kedua, seperti berikut:

$\mathrm{D}(2.1)=\sqrt{(12,00-181.420)^{2}}=181408,17$

$\mathrm{D}(2.2)=\sqrt{(12,00-1.313 .617)^{2}}=1313604,67$

$\mathrm{D}(2.3)=\sqrt{(12,00-512.821)^{2}}=512809,00$

Sampai dengan $\mathrm{D}(2.34)$

4 Menentukan posisi cluster masing-masing data produksi jagung berdasarkan jarak minimum data terhadap pusat cluster. Data yang memiliki jarak terkecil dengan centroid akan menjadi anggota pada kelompok tersebut. Berikut ini merupakan tabel posisi data dengan tiap cluster pada iterasi ke-1 dengan menggunakan bantuan tanda (1) yang mengatakan data menjadi anggota pada cluster.

Tabel 4.Posisi data hasil pengelompokkan tiap cluster (Iterasi 1)

\begin{tabular}{lcc}
\hline \multicolumn{1}{c}{ PPProPPPRvinsi } & c1 & c2 \\
\hline ACEH & & 1 \\
SUMATERA UTARA & 1 \\
SUMATERA BARAT & 1 \\
RIAU & & 1 \\
JAMBI & 1 \\
SUMATERA SELATAN & 1 \\
BENGKULU & 1 \\
LAMPUNG & & 1 \\
KEP. BANGKA BELITUNG & & 1 \\
KEP. RIAU & & 1 \\
DKI JAKARTA & 1 \\
JAWA BARAT & 1 & 1 \\
JAWA TENGAH & \\
DI YOGYAKARTA & 1 & 1 \\
JAWA TIMUR & & \\
BANTEN & & 1 \\
BALI & & 1 \\
NUSA TENGGARA BARAT & &
\end{tabular}




NUSA TENGGARA TIMUR
KALIMANTAN BARAT
KALIMANTAN TENGAH
KALIMANTAN SELATAN
KALIMANTAN TIMUR
KALIMANTAN UTARA
SULAWESI UTARA
SULAWESI TENGAH
SULAWESI SELATAN
SULAWESI TENGGARA
GORONTALO
SULAWESI BARAT
MALUKU
MALUKU UTARA
PAPUA BARAT
PAPUA

5 Menghitung titik pusat baru menggunakan hasil dari setiap laju inflansi pada masing-masing cluster Contoh perhitungan titik pusat baru pada cluster $\mathrm{x}$ adalah :

$$
\begin{aligned}
& \mathbf{C}_{1} \mathbf{x}=\frac{5.825 .971}{1}=5.825 .971 \\
& \mathbf{C}_{2} \mathbf{x}=1.313 .617+512.84+1.78 .203+1.001 .121+312.447+621.367+641.246+426.968+ \\
& 1.424 .689+660.348 / 10=869.583 \\
& \mathbf{C}_{3} \mathbf{x}=181.420+32.344+168.807+840+783+12+3.011 .289+14.1444+55.271+149.732+ \\
& 8.174+113.63+8.347+1.080+426.968+151.060+69.061+100.562+13.981+22.157+ \\
& 2.159+6.849 / 23=183.790
\end{aligned}
$$

6 Selanjutnya dilakukan kembali langkah 4 sampai 5. Jika nilai centroid hasil iterasi dengan nilai centroid

\begin{tabular}{|c|c|c|c|}
\hline Provinsi & c1 & c2 & iterasi 2 jarak terpendek \\
\hline ACEH & 4237209,92 & 128321,05 & 128321,05 \\
\hline SUMATERA UTARA & 3105013,42 & 1003875,45 & 1003875,45 \\
\hline SUMATERA BARAT & 3905809,08 & 203079,79 & 203079,79 \\
\hline RIAU & 4386285,92 & 277397,05 & 277397,05 \\
\hline JAMBI & 4384829,75 & 275940,88 & 275940,88 \\
\hline SUMATERA SELATAN & 4249823,58 & 140934,71 & 140934,71 \\
\hline BENGKULU & 4337797,92 & 228909,05 & 228909,05 \\
\hline LAMPUNG & 2637427,42 & 1471461,45 & 1471461,45 \\
\hline KEP. BANGKA BELITUNG & 4417789,75 & 308900,88 & 308900,88 \\
\hline KEP. RIAU & 4417846,92 & 308958,05 & 308958,05 \\
\hline DKI JAKARTA & 4418618,08 & 309729,21 & 309729,21 \\
\hline JAWA BARAT & 3417508,92 & 691379,95 & 691379,95 \\
\hline JAWA TENGAH & 1407341,25 & 2701547,62 & 1407341,25 \\
\hline DI YOGYAKARTA & 4106183,42 & 2705,45 & 2705,45 \\
\hline JAWA TIMUR & 1407341,25 & 5516230,12 & 1407341,25 \\
\hline BANTEN & 4404186,58 & 295297,71 & 295297,71 \\
\hline BALI & 4363359,58 & 254470,71 & 254470,71 \\
\hline NUSA TENGGARA BARAT & 3797262,75 & 311626,12 & 311626,12 \\
\hline NUSA TENGGARA TIMUR & 3777384,25 & 331504,62 & 331504,62 \\
\hline KALIMANTAN BARAT & 4268898,25 & 160009,38 & 160009,38 \\
\hline KALIMANTAN TENGAH & 4410456,08 & 301567,21 & 301567,21 \\
\hline KALIMANTAN SELATAN & 4304992,08 & 196103,21 & 196103,21 \\
\hline KALIMANTAN TIMUR & 4410282,75 & 301393,88 & 301393,88 \\
\hline KALIMANTAN UTARA & 4417550,08 & 308661,21 & 308661,21 \\
\hline SULAWESI UTARA & 3991661,75 & 117227,12 & 117227,12 \\
\hline SULAWESI TENGAH & 4267570,58 & 158681,71 & 158681,71 \\
\hline SULAWESI SELATAN & 2993941,08 & 1114947,79 & 1114947,79 \\
\hline SULAWESI TENGGARA & 4349029,58 & 240140,71 & 240140,71 \\
\hline GORONTALO & 3758281,92 & 350606,95 & 350606,95 \\
\hline SULAWESI BARAT & 4318068,08 & 209179,21 & 209179,21 \\
\hline
\end{tabular}
sebelumnya bernilai sama atau nilai centroid sudah optimal serta posisi cluster data produksi tanaman jagung tidak mengalami perubahan lagi maka proses iterasi berhenti. Namun jika nilai centroid tidak sama atau belum optimal serta posisi data produksi tanaman jagung masih berubah maka proses iterasi berlanjut pada iterasi berikutnya.

Iterasi 2

Tabel 5. Hasil perhitungan jarak data ke titik pusat cluster (Iterasi 2) 


\section{MALUKU \\ MALUKU UTARA \\ PAPUA BARAT \\ PAPUA}

$$
\begin{aligned}
& 4404649,42 \\
& 4396473,08 \\
& 4416470,75 \\
& 4411781,08
\end{aligned}
$$

295760,55
287584,21
307581,88
302892,21

295760,55

287584,21

307581,88

302892,21

7 Setelah data nilai pusat cluster iterasi 2 didapat maka langkah selanjutnya adalah melakukan perhitungan jarak terhadap data produksi tanaman jagung dengan titik pusat (centroid) pada cluster kedua

Perhitungan produksi tanaman jagung pertama dengan centroid cluster pertama, seperti berikut:

$\mathrm{D}(1.1)=\sqrt{(4418630,08-181.420)^{2}}=4237209,92$

$\mathrm{D}(1.2)=\sqrt{(4418630,08-1.313 .617)^{2}}=3105013,42$

$\mathrm{D}(1.3)=\sqrt{(4418630,08-512.821)^{2}}=3905809,08$

Dan seterusnya sampai dengan $\mathrm{D}(1.34)$

Perhitungan produksi tanaman jagung pertama dengan centroid cluster kedua, seperti berikut:

$\mathrm{D}(2.1)=\sqrt{(309741,21-181.420)^{2}}=128321,05$

$\mathrm{D}(2.1)=\sqrt{(309741,21-1.313 .617)^{2}}=1003875,45$

$\mathrm{D}(2.1)=\sqrt{(309741,21-512.821)^{2}}=203079,79$

Dan seterusnya sampai dengan $\mathrm{D}(2.34)$

Tabel 6.Centroid data awal (Iterasi 2)

\begin{tabular}{cc} 
Cluster & Nilai \\
\hline MAX & 4418630,08 \\
MIN & 309741,21 \\
\hline
\end{tabular}

Data yang memiliki jarak terkecil dengan centroid akan menjadi anggota pada kelompok tersebut. Berikut ini merupakan tabel posisi data dengan tiap cluster pada iterasi ke-2 dengan menggunakan bantuan tanda (1) yang mengatakan data menjadi anggota pada cluster.

Tabel 7.Posisi data hasil pengelompokkan tiap cluster (Iterasi 2)

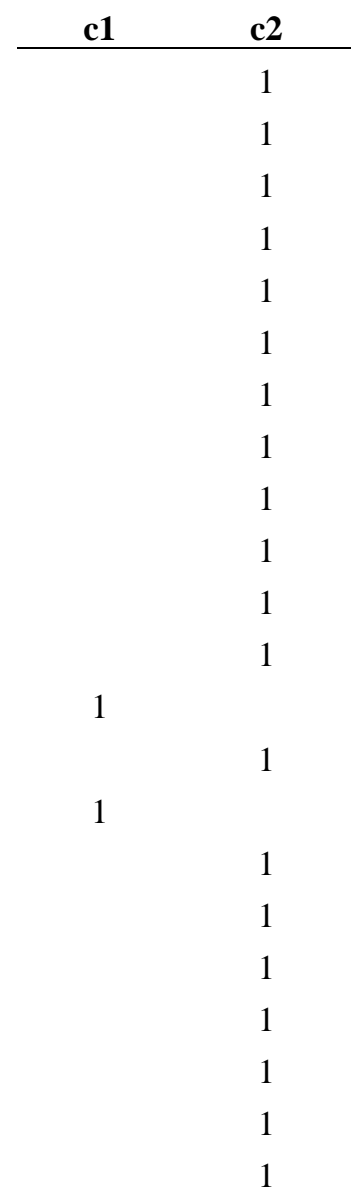




\begin{tabular}{l}
1 \\
1 \\
1 \\
1 \\
1 \\
1 \\
1 \\
1 \\
1 \\
1 \\
1 \\
1 \\
\hline
\end{tabular}

\subsection{Tampilan RapidMiner}

Untuk mendapatkan hasil pengelompokkan pada tahap selanjutnya dilakukan dengan mengklik tanda panah biru yang terdapat di posisi tengah atas pada toolbar. Tahap ini akan menampilkan hasil akhir serta langkah terakhir dalam penggunaan tools rapidminer. Dapat dilihat pada gambar 1:

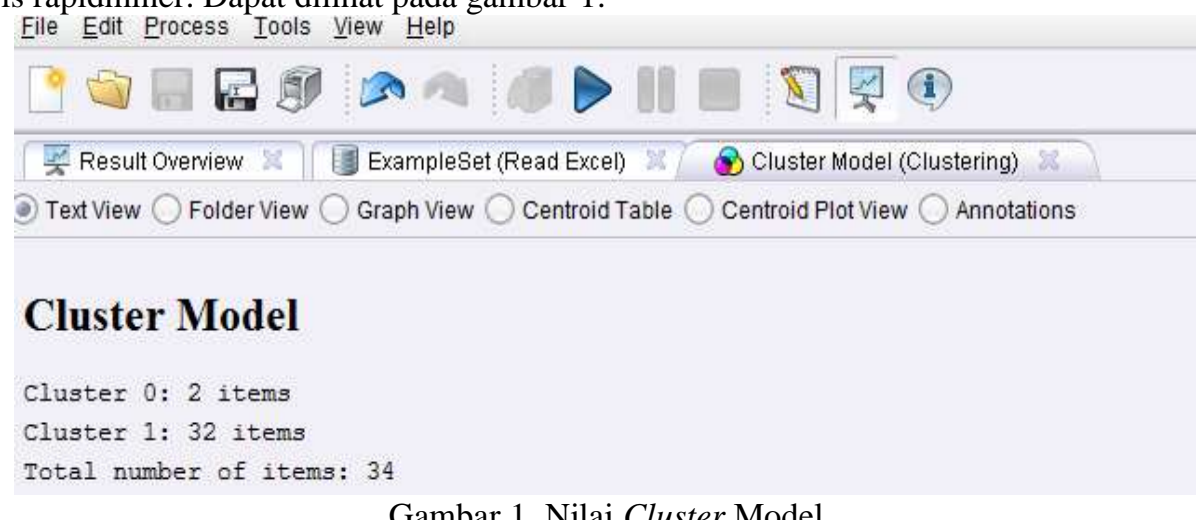

Gambar 1. Nilai Cluster Model

Keterangan :

1. Jumlah Cluster 0 (Tinggi) berjumlah 2 Items

2. Jumlah Cluster 1 (Rendah) berjumlah 32 Items

3. Jumlah keseluruhan items adalah 34

Sehingga dapat diketahui hasil pengelompokkan rapidminer dapat dilihat pada gambar sebagai berikut :

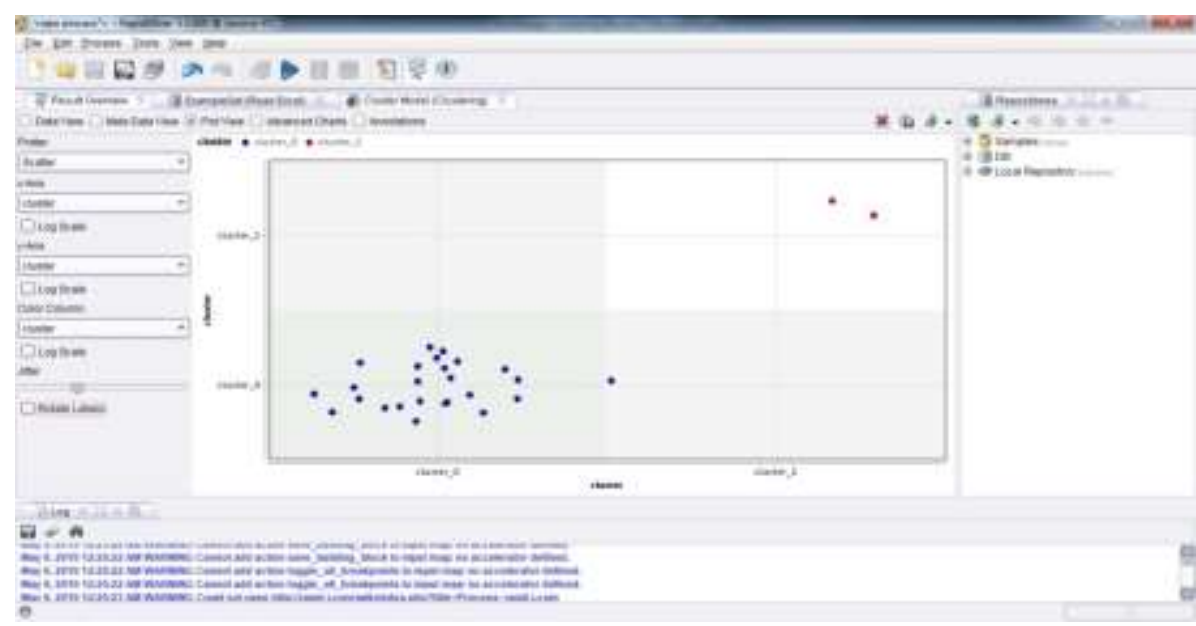

Gambar 2. Hasil Pengelompokan

Berdasarkan pada gambar dapat dilihat bahwa kelompok tinggi memiliki 2 node, sedangkan pkelompok rendah memiliki 32 node. 


\section{KESIMPULAN}

Adapun kesimpulan yang dapat di ambil pada tekhnik data mining dalam clustering produksi jagung menurut provinsi dengan algoritma k-means ini adalah sebagai berikut

1. Algoritma k-means clustering ini dapat membantu peneliti mengelompokkan produksi jagung pada setiap provinsi di indonesia. Dari data poduksi jagung di indonesia dapat di ketahui terdapat 2 provinsi dengan cluster tingkat tinggi yaitu: Jawa Tengah dan Jawa Timur dan 32 provinsi dengan cluster tingkat rendah yaitu : Aceh, Sumatera Utara, Sumatera Barat, Riau, Jambi, Sumatera Selatan, Bengkulu, Lampung, Kepulauan Bangka Belitung, Kepulauan Riau, DKI Jakarta, Jawa Barat, DI Yogyakarta, Banten, Bali, Nusa Tenggara Barat, Nusa Tenggara Timur, Kalimantan Barat, Kalimantan Tengah, Kalimantan Selatan, Kalimantan Timur, Kalimantan Utara, Sulawesi Utara, Sulawesi Tengah, Sulawesi Selatan, Sulawesi Tenggara, Gorontalo, Sulawesi Barat, Maluku, Maluku Utara, Papua, Papua Barat.

2. Aplikasi rapidminer ini dapat membantu peneliti mengelompokkan produksi jagung pada setiap provinsi di indonesia. Perhitungan manual algoritma k-means clustering dalam mengelommpokkan produksi jagung dna penerapan di Rapidminer menunjukkan hasil yang sama

\section{REFERENCES}

[1] A. Saleh, "Klasifikasi Metode Naive Bayes Dalam Data Mining Untuk Menentukan Konsentrasi Siswa ( Studi Kasus Di Mas Pab 2 Medan )," Konf. Nas. Pengemb. Teknol. Inf. Dan Komun., Pp. 200-208, 2014.

[2] R. Setiawan And N. Tes, "Penerapan Data Mining Menggunakan Algoritma K-Means Clustering Untuk Menentukan Strategi Promosi Mahasiswa Baru ( Studi Kasus : Politeknik Lp3i Jakarta ),” Vol. 3, No. 1, Pp. 76-92, 2016.

[3] 2015 Surmayanti, Et Al, "Penerapan Analysis Clustering Pada Penjualan Komputer Dengan Perancangan Aplikasi Data Mining Menggunakan Algoritma K-Means," Pros. Semin. Ilm. Nas. Teknol. Komput., Vol. 1, No. Senatkom, Pp. 50-59, 2015.

[4] A. K. Wardhani, "Implementasi Algoritma K-Means Untuk Pengelompokkan Penyakit Pasien Pada Puskesmas Kajen Pekalongan," Vol. 14, Pp. 30-37, 2016. 